\title{
OSTEOCHONDRITIS DISSECANS OF THE PATELLA
}

\author{
Major N. E. CETTI, M.A., B.M., B.Ch., F.R.C.S., R.A.M.C. \\ Military Hospital, Tidworth*
}

SUMMARY: A case of osteochondritis dissecans of the patella is described and the literature reviewed.

\section{Case Report}

A healthy sixteen year old junior soldier presented to us in the summer of 1973 with a painful and swollen left knee. He gave a history of aching in both knees since the age of twelve, especially after strenuous cycling. He could remember no specific injury. Three weeks before presentation he experienced aching in the left knee, but no swelling. Three days later, during an assault course, he jumped a six-foot wall and landed normally, but there was a ' crack' in the left knee which 'gave way'. He was able to rise, but the knee was 'clicking' and painful and swelled within the hour. $\mathrm{He}$ was treated, in the first instance, with rest and supporting bandages, being subsequently referred to the Military Hospital, Tidworth. An X-ray of the knee at this time showed an area of rarefaction in the patella. An initial period of conservative management was unsuccessful. He was therefore admitted to hospital.

On examination there was a mild effusion of the left knee with slight quadriceps wasting on that side. There was full flexion, but a block to full extension and considerable pain on patellar friction. The medial joint line was tender and there was no ligamentous laxity. Further X-ray showed a more definite crater in the articular surface of the left patella (Fig. 1).
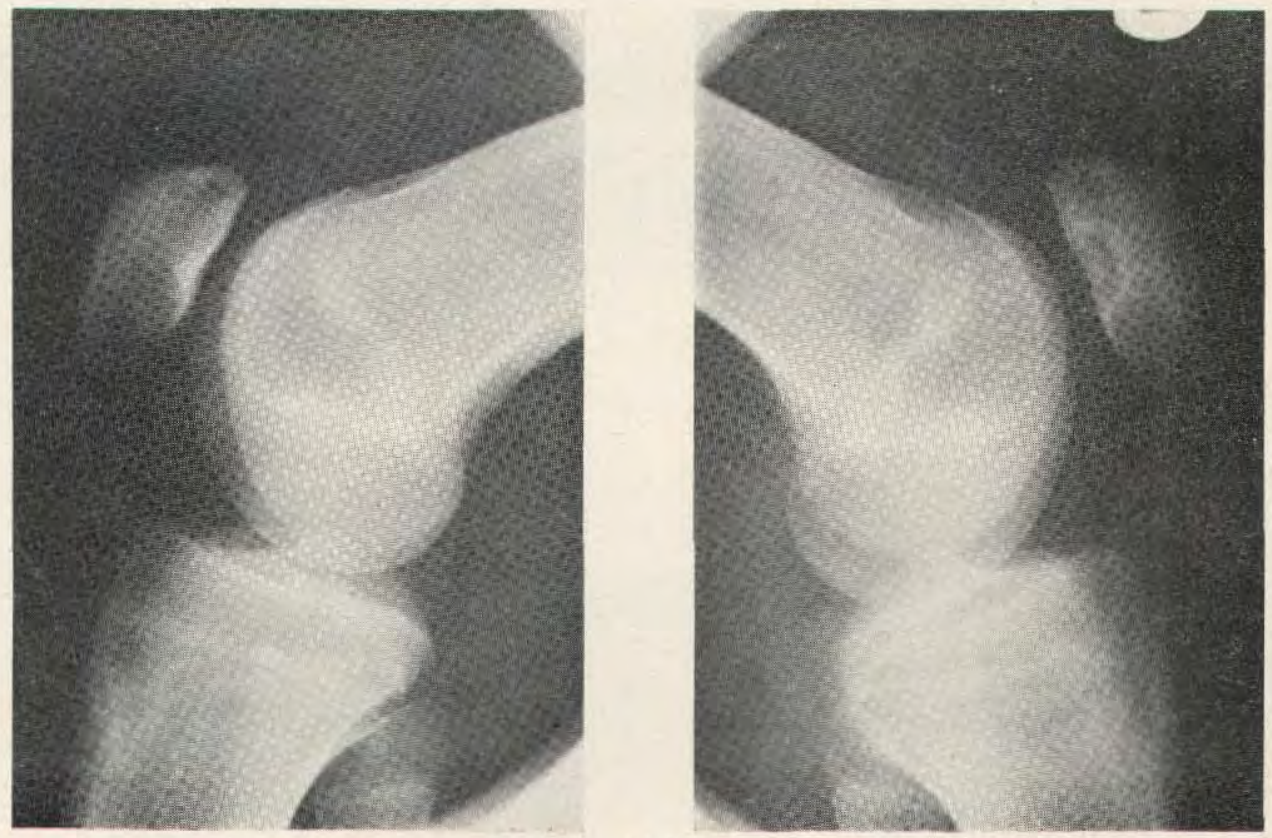

Fig. 1. Lateral X-rays of right and left knee on admission to hospital.

* Now British Military Hospital, Dhekelia, BFPO 53. 
At operation via a medial arthrotomy incision, an osteochondritis dissecans defect was found within the medial articular surface of the patella with much surrounding fibrillation of cartilage (Fig. 2). A small loose body was found in the medial side of the joint and a large cartilaginous loose body in the supra-patellar pouch (Fig. 3). There

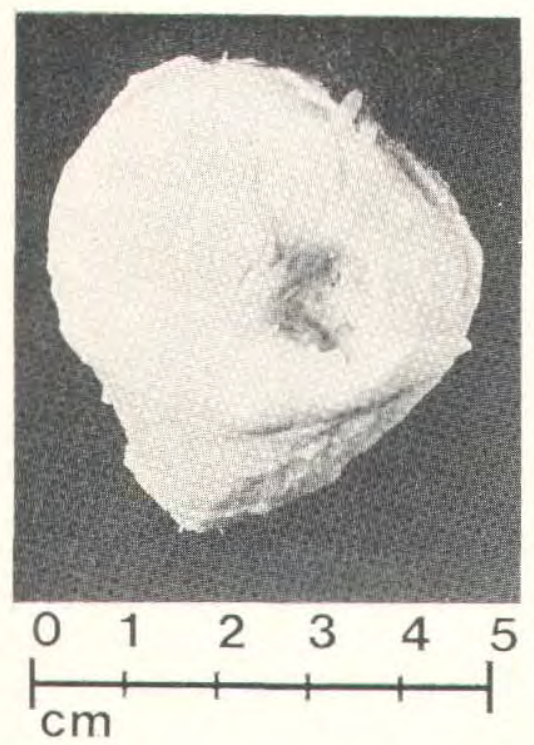

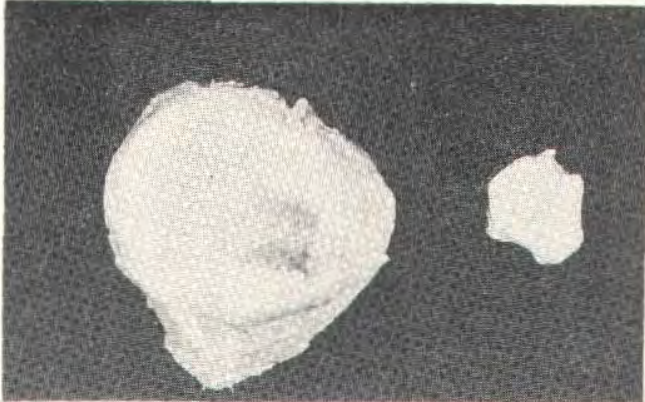

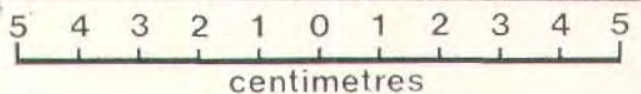

Fig. 3 ahove. The left patella and large cartilaginous loose body removed at operation.

Fig. 2 left. Close-up view of the articular surface of the left patella after removal.

was no other abnormality found. The patella and loose bodies were removed. The patient made an excellent recovery and within three months had returned to full military duties.

\section{Discussion}

The knee is the commonest site for osteochondritis dissecans, this joint and the elbow making up ninety per cent of reported cases (Stillman 1966). Within the knee the lateral aspect of the medial condyle is the most frequently affected (Green 1966). Osteochondritis dissecans of the patella is uncommon (Smillie 1962). Aichroth (1971) found in a survey of two hundred cases of osteochondritis dissecans of the knee five with lesions of the patella.

There are thirty cases reported in the literature (Rombold 1936, Hutchison 1943, Kleinberg 1949, De Palma 1954, Heywood 1961, Smillie 1962, Rideout, Davis and Navani 1966, Pantazopoulos and Exarchou 1971, and Aichroth 1971), details of some of the cases are given in Table $\mathrm{I}$.

The disease is more often unilateral than bilateral and predominantly affects males between the ages of fifteen and twenty-five years, who take an active part in sport. A history of specific trauma is by no means the rule.

Osteochondritis dissecans of the patella affects the medial articular facet twice as often as either the lateral or central articular surfaces. In those cases subjected to surgery, the ischaemic segment was found either still attached, but easily detachable, or already free as one or more loose bodies. Several cases showed normal surrounding 
Table I

\begin{tabular}{|c|c|c|c|c|c|c|}
\hline Source & Age & Sex & $\begin{array}{l}\text { Bilateral or } \\
\text { Unilateral }\end{array}$ & Site on patella & Loose body & Trauma \\
\hline Smillie (1962) & $\begin{array}{l}20 \\
18 \\
16 \\
\\
20 \\
15 \\
22 \\
34\end{array}$ & $\begin{array}{l}\mathrm{M} \\
\mathrm{M} \\
\mathrm{M} \\
\mathrm{M} \\
\mathrm{M} \\
\mathrm{M} \\
\mathrm{M}\end{array}$ & $\begin{array}{l}\text { Bilateral } \\
\text { Unilateral } \\
\text { Bilateral } \\
\text { Unilateral (L) } \\
\text { Unilateral (R) } \\
\text { Unilateral (L) } \\
\text { Unilateral (R) }\end{array}$ & $\begin{array}{l}\text { Infero-medial } \\
\text { Infero-medial } \\
\text { Left medial } \\
\text { right lateral } \\
\text { Medial } \\
\text { Not known } \\
\text { Medial } \\
\text { Not known }\end{array}$ & $\begin{array}{l}\text { Yes } \\
\text { No } \\
\text { Yes } \\
\text { Yes } \\
\text { Yes } \\
\text { Yes (3) } \\
\text { Yes } \\
\text { Yes }\end{array}$ & $\begin{array}{l}\text { Not known } \\
\text { Not known } \\
\text { No } \\
\text { No } \\
\text { Yes } \\
\text { Yes } \\
\text { Yes } \\
\text { Yes }\end{array}$ \\
\hline Kleinberg (1949) & 16 & M & Unilateral (L) & Infero-medial & Yes & Not known \\
\hline $\begin{array}{l}\text { Pantazopoulos and } \\
\text { Exarchou (1971) }\end{array}$ & $\begin{array}{l}17 \\
15 \\
26 \\
23\end{array}$ & $\begin{array}{l}\mathrm{M} \\
\mathrm{M} \\
\mathrm{F} \\
\mathrm{M}\end{array}$ & $\begin{array}{l}\text { Unilateral (R) } \\
\text { Unilateral (L) } \\
\text { Unilateral (L) } \\
\text { Unilateral (L) }\end{array}$ & $\begin{array}{l}\text { Lateral } \\
\text { Infero-lateral } \\
\text { Lateral } \\
\text { Middle }\end{array}$ & $\begin{array}{l}\text { No } \\
\text { No } \\
\text { Yes } \\
\text { No }\end{array}$ & $\begin{array}{l}\text { No } \\
\text { No } \\
\text { No } \\
\text { No }\end{array}$ \\
\hline $\begin{array}{l}\text { Rideout, Davis and } \\
\text { Navani (1966) }\end{array}$ & $\begin{array}{l}15 \\
16 \\
19\end{array}$ & $\begin{array}{l}\mathrm{M} \\
\mathrm{M} \\
\mathrm{M}\end{array}$ & $\begin{array}{l}\text { Unilateral (R) } \\
\text { Bilateral } \\
\text { Unilateral (R) }\end{array}$ & $\begin{array}{l}\text { Lateral } \\
\text { Not known } \\
\text { Middle }\end{array}$ & $\begin{array}{l}\text { No } \\
\text { Not known } \\
\text { Not known }\end{array}$ & $\begin{array}{l}\text { No } \\
\text { Probable } \\
\text { Yes }\end{array}$ \\
\hline Rombold (1936) & 24 & M & Unilateral (L) & Middle & No & No \\
\hline Hutchison (1943) & 45 & M & Unilateral (L) & Not known & Not known & Yes \\
\hline De Palma (1954) & 36 & M & Unilateral & Not known & Yes & Not known \\
\hline
\end{tabular}

Note: Six further cases mentioned by Smillie (1962). Only details given-Site of lesion on patella and all infero-medial.

articular cartilage, though most had associated chondromalacia patellae, extending considerably beyond the peripheral margins of the avascular segment (Crenshaw 1971).

Treatment of the reported cases has included conservative rest and support, curetting of the crater, removal of loose bodies and patellectomy. Satisfactory results have been claimed in particular cases for this whole spectrum of treatment.

This present case is the thirty-first recorded in the English literature. The initial symptoms could well have been mistaken for those of chondromalacia patellae until the acute episode, when the avascular segment became a loose body. There was indeed chondromalacia as well as osteochondritis and this has been reported in several of the cases in the literature. However chrondromalacia patellae is a common condition while osteochondritis dissecans of the patella is rare, so that this finding must be regarded as coincidental and not indicative of different degrees of the same condition.

The aetiology of osteochondritis dissecans of the patella remains obscure. The fact that the articular surface of the femoral condyles is normal does not support the view that direct impingement of the patella on the condyles is the cause (Aichroth 1971). Rather would trauma seem to be the final insult, which dislodges the already ischaemic segment. End-artery thrombosis would seem to be the most likely explanation (WatsonJones 1960), but why these vessels should be involved in this particular group of young men is not clear. 


\section{Acknowledgements}

I should like to thank Lieutenant-Colonel W. J. Pryn, O.B.E., F.R.C.S. for his help with the script and permission to study the patient under his care. The Photographic Department of the Royal Army Medical College, Millbank provided the excellent illustrations.

\section{REFERENCES}

Aichroth. P. (1971). J. Bone Jt Surg, 53B, 440.

Crenshaw, A. H. (1971). Campbell's Operative Orthopaedics. 5th ed. Mosby. St. Louis. Vol. 1. P. 955. De Palma, A. F. (1954). Diseases of the Knee. Lippincott. Philadelphia. P. 475.

Green, J. P. (1966) J. Bone .J Surg. 48B-1, 82.

HeYwoed, A. W. B. (1961). J. Bone Jt Surg. 43B, 508.

Hutchison, R. G. (1943). Brit. J Radiol 16, 147.

KLFINBERG, S. (1949). J. Bone Jt Surg. 31A, 185.

Pantazoupoulos, T. and Exarchou, V. (1971). J. Bone Jt Surg. 53A, 1205.

Rideout, D. F., Davis, S. and NAvant, S. V. (1966). Brit. J. Radiol. 39, 673.

Romiold, C. (1936). J. Bone Jt Surg. 18, 230.

Smillie, I. S. (1962). Injuries of the Knee Joint. 3rd ed. Williams \& Wilkins. Baltimore. P. 403.

Stillman, B. S. (1966). J. Bone Jt Surg. 48B-1, 64.

WATSON-JONES, R. (1960). Fractures \& Joint Injuries. 4th ed. E. \& S. Livingstone Edinburgh Vol 1. P. 97.

\section{BANKERS ORDER}

From (NAME AND RANK IN BLOCK LETTERS)

To the Manager (Bank)

(Branch)

(Address)

Please pay Messrs. Williams \& Glyn's Bank LtD., Kirkland House, Whitehall, S.W.1 for the credit of the funds of the Journal of the Royal Army Medical Corps, account number 45273213 , the sum of

$$
\begin{array}{ll}
{ }^{*} 2_{2.50} & \text { Journal and Magazine or } \\
{ }^{*} 2.00 & \text { Journal only or } \\
{ }^{*} 0.60 & \text { Magazine only. }
\end{array}
$$

being my subscription for the year beginning 1 st 19

and continue such payments yearly on the 1 st till further notice.

Full Postal Address

\section{Signature}

\section{Date}

To be sent to Manager, Journal of the R.A.M.C., R.A.M. College, Milibank, London, S.W.1 for record and transmission to bank.

- Delete whichever is not applicable. 